\title{
Qualitative Review of Ethics from Religion, Culture and Corporate Scandals
}

\section{Premkumar Balaraman}

\author{
Associate Professor, Department of Management Studies, Adigrat University, Ethiopia
}

\begin{abstract}
Purpose and aim: Ethical breaches have become a common phenomenon across the globe, especially by big companies and top level executives, and have resulted in major corporate blunders, accounting scandals ending up in bankruptcy and deception of the various stakeholders. There is a need to make an introspection of ethical values and its impact on businesses, so that the future corporate social responsibility and ethical leadership of the executives can have a binding. The paper investigates the role of religion and culture on ethics \& morals and how it can be applied towards betterment of business conduct. Also it attempts to explore the root causes of corporate scandals and from an ethical perspective.

Methodology: Literature review and case analysis of secondary data are the key sources of information in the study on a qualitative perspective. In the qualitative analysis of ethical contributions from religions and culture, the various themes are identified and grouped based on common grounds. Tabulation of the causal factors of corporate scandals, enables to clearly identify the root cause of unethical business practices and immoral leadership. The various findings are to be taken in a positive note for the future corporate businesses and ethical leadership of executives.
\end{abstract}

Findings and novelty: The various reflections from literature on global religions, cultures, Indian mythology, classical Tamil literature on ethics, leadership and behavior, identify various morals, virtues and founding pillars for mankind, especially for business and nation governance perspective in these changing times of the Globalized world pestered with scandals and fraud. These moral values and ethical guides have passed the test of time, and fit enough to be reinstated in the mainstream of ethical and legal conduct of firms and Governments to serve the stakeholders and society at its best. From the pareto analysis of the various corporate scandals on an ethical perspective, it is inferred that $80 \%$ of the root causes of the corporate scandals could be attributed to the ethical dimension of abstaining from fraud (72.22\%). The paper is very novel in exploring the ethical perspectives from various dimensions of culture and religion across the globe. Also uniquely the paper identifies many commonalities from these ethical sources namely, transparency, trust, sustainability, justice and abstaining from fraud \& corruption.

Conclusion and future research: The paper concludes that todays globalized businesses needs to look into ethical values and moral principles explored in the study from the various cultural and religious dimensions, and can aid in preventing ethical misconduct and improving corporate sustainability, brand image and reputation. The future researchers can explore the various global legislative frameworks, in assessing the ethical strengths and weaknesses, since legal loopholes pave way for many corporate blunders. Also the existing climate and culture of global organizations can be assessed for ethical training, moral code of conduct and ethical decsion making.

Keywords: ethics, values, religion, culture, scandals.

JEL Classification: M14, K20.

(C) The Author, 2017. This article is published with open access at ARMG Publishing.

\section{Introduction}

With the civilized world, quality of life and globalized form of business moving ahead steadily in developing as well as developed countries, there also seems to be erosion in ethical conduct in all spheres of life and especially on the corporate governance of private as well as public organizations. "Ethics are the inner guiding moral principles, values, and benefits that people use to analyze and interpret a situation and then decide what is right or the appropriate way to behave" (Jones and George, 2009). But the wave of scandals that has inundated business since Enron has had far reaching consequences. Questions of ethics have taken on particular urgency as companies grapple with increased media scrutiny of governance matters, as well as of 
corporate social and environmental issues. Ethics are in fact so critical to long-term business sustainability that they will increasingly form the basis of serious executive leadership.

The paper on business ethics is qualitative in nature and revisits the fundamentals of ethics applied for Business, from multiple sources like religion and culture. Especially the major global religions and their philosophical standpoints of ethics for human life are taken as crucial means for business perspectives. The various themes of this analysis identifies the areas of focus of ethics in ancient times, time tested moral values that can be taken forward to address current day ethical issues. Also some of the global corporate scandals that shook the corporate world in recent decades and country specific case of India on public sector scams are also analysed qualitatively to identify the various areas of ethical loopholes.

\section{Objective of the study}

To investigate the role of religion and culture on ethics \& morals of business.

$>$ To explore the root causes of corporate scandals from an ethical perspective.

Need for the study

Sighting the importance of corporate ethics in the long term running of business, sustainability, and stakeholder responsibility, there arises the compulsion for the researchers and practitioners of business to understand in depth the essence of ethics and how it can be applied for business frontiers. With so much influence of morality and value systems on ethical business decision making, it compels the researcher to do an honest analysis on the biases and contribution of morality and value system from various sources like culture and religion. As the sources of morality and value system are too broad to assess on a global perspective, the paper limits its scope to critically examine and evaluate the influence of religion and culture from established ethical perspectives and developing countries like India. Some of the recent legislations that impact global business on ethical dimensions are also assessed.

Also to understand the grey area of pitfalls of unethical business decisions, fraudulent corporate actions and erroneous corporate governance, some of the major corporate scandals of recent decades are also explored to find the possible root causes for such immoral and unethical business behavior on part of the executives and as well as the organizations as a whole. Henceforth the need for the study is best justifiable, as the deeper understanding of business ethics shall lead to good corporate governance, moral leadership and infusion of ethical values in organizational culture.

\section{Literature review}

\section{Definition of business ethics}

Business ethics (also known as corporate ethics) is a form of applied ethics that examines ethical principles and moral or ethical problems that arise in a business environment. (Drucker, 1991). It applies to all aspects of business conduct and is relevant to the conduct of individuals and business organizations as a whole. There are many definitions for business ethics; they all stress the fact that managers must balance the ideal against the practical, the need to produce a reasonable profit for the company's shareholders with honesty in business practices, safety in the workplace, and larger environmental and social issues. The scope of business ethics has widened since organizations are getting larger and most of them are taking the form of multinational corporation.

\section{Distinction between ethics and morality}

Ethics is the study of what "ought" to be. It is a theoretical study and is otherwise referred to as the study of morality. We are interested in how life ought to be lived, morally speaking. As a branch of philosophy, ethics has three components (Feiser, 2003): "metaethics" studies the sources and meaning of ethical terms; "normative ethics" does the more practical task of examining the moral standards that regulate right and wrong conduct; and "applied ethics" examines controversies such as abortion, infanticide, animal rights, environmental concerns, homosexuality, capital punishment or nuclear war. Mores or morals pertain to the existing morality, the "what is." It is usually the business of ethics to supplant mores. The "what ought" is believed to be a better alternative to the "what is." Though the ethical life is based on religious tenets, it cannot also be ignored that it is possible to have ethics even without religion. And such instances of ethics include that of ethics of Plato and Aristotle, the utilitarian ethics and the ethics of Kant, among others, which are based on reason or on what is natural. 


\section{Impact of morality on ethical decision making}

To practice and understand ethical decision making, professionals must first understand the three steps/stages involved in the ethical decision making process proposed by James Rest, namely, moral recognition (to identify that a situation involves a moral issue), moral evaluation (evaluation of inherent consequences of each possible course of action, depending on a person's background (e.g. cultural, socioeconomic, educational etc.),) and moral intention (prioritizing of moral values, select and choose the ethical values that will ultimately determine their action) (Cipoletti, 2013). According to Jones and George (2009), there are four ethical principles that affects business decisions; they are:

Utilitarian rule: It is an ethical decision that produces the greatest good for the largest number of people; Moral right rule: It is a decision that best maintains and protects the fundamental or inalienable rights and privileges of the people affected by it;

Justice rule: It is a decision that distributes benefits and harm among people and groups in a fair, equitable, or impartial way;

Practical rule: It is a decision that a manager has no reluctance to communicate to people outside the company because the typical person in a society would think it is acceptable.

\section{Important jargons in the field of business ethics}

Corporate social responsibility (CSR): CSR refers to a business practice that involves participating in initiatives that benefit society. (Sammi Caramela, 2013). Definitions of CSR expanded during the 1960s and proliferated during the 1970s. In the 1980s, there were fewer new definitions, more empirical research, and alternative themes began to mature. These alternative themes included corporate social performance (CSP), stakeholder theory, and business ethics theory. The Pyramid of corporate social responsibility; CSR and organizational stakeholders; Moral management and stakeholders was explored and proposed by Carroll. (Carroll, 1991).

Corporate governance (CG): CG concerns the very fundamental question of who owns a corporation, in whose interests it is run, and by whom it is ultimately controlled (Miwa, 2006). CG is also defined as the mechanisms, processes, and relations by which corporations are controlled (Shailer, 2004). CG includes the processes through which corporate goals and objectives are determined, measured and pursued in the context of the social, regulatory, and commercial environment.(Tricker, 2009).

Corporate scandal \& fraud: Corporate scandals are defined as rare events occurring at the apex of corporate fame when managerial fraud suddenly emerges in conjunction with a significant gap between perceived corporate success and actual economic conditions. (Zona, Minoja, \& Coda, 2013). Mohammed (2004), defines fraud as deliberate deception to obtain illicit material gain, and includes embezzlement and asset misappropriation in the definition.

Corporate image / corporate reputation: The ways in which the company projects its images: its behavior, communication and symbolism. Corporate reputation may have different dimensions and is issue specific, and different stakeholder groups may have different perceptions of corporate reputations (Walker, 2010).

Corporate sustainability: It is comprehensive and multidimensional and includes the effects of incorporating sustainability into corporate strategy and external communications to corporate stakeholders; the consequences of including an organization's supply chain in sustainability efforts; an illustration of the potential synergy between innovation and sustainability; the consequences of incorporating economic, ecological- environmental, and equity-social concerns in strategic decisions and design processes; and the ramifications of serving as an industry thought leader in shaping sustainability regulatory policies (Amini \& Bienstock, 2014).

Values: According to Rokeach (1973), values represent basic convictions that "a specific mode of conduct or end-state of existence is personally or socially preferable to an opposite or converse mode of conduct or end-state of existence."

Trust: Trust is a psychological state that exists when you agree to make yourself vulnerable to another because you have positive expectations about how things are going to turn out (Simpson, 2007). The key characteristics that lead us to believe a leader is trustworthy, includes (Colquitt, Scott, and LePine, 2007):

$>$ Integrity (refers to honesty and truthfulness),

$>$ Benevolence (means the trusted person has your interests at heart, even if yours aren't necessarily in line with theirs, caring and supportive behavior), and 
Ability (encompasses an individual's technical and interpersonal knowledge and skills).

\section{Religion and its impact on values, morality and ethics}

The higher the visibility of a meaning system, the higher the chances are of recognition by the citizens. While American sociologists of religion like Stark and Iannaccone (Iannaccone et al., 1997) assume that free competition on the religious market will increase visibility and quality of religious products and as a consequence stimulate religious participation, theories of secularization often maintain that religion becomes increasingly invisible in modern societies. In the simplified model in Figure 1, it is reduced to an impact of presentation of religion on the macro-level on exposure to religion on the micro-level. Further complexity has to be added if the path from exposure to religion to action is elaborated on the basis of the theory of planned behavior (Ajzen and Fishbein, 1975): Individuals who are continuously exposed to religion will adopt certain beliefs and values which then structure attitudes and beliefs about behavior.

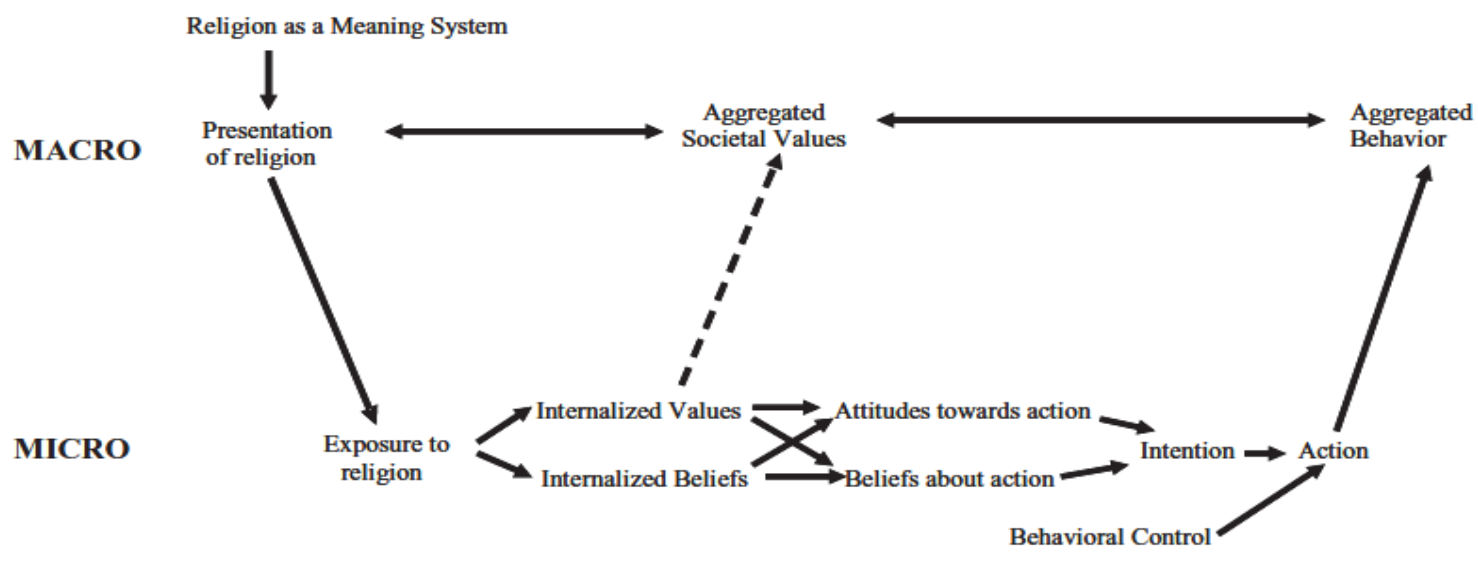

Figure 1. The relationship between religion, values, and action in a simplified micro-macro-model

Source: Adapted from Wolfgang (2009).

\section{Methodology}

The paper explores from a qualitative perspective the fundamentals of business ethics from various global perspectives, religious and cultural dimensions, explore the recent legislations on ethical frameworks and also a closer look into the recent trend in corporate scandals in identifying the major area of lacunae in ethical conduct of businesses.

Literature review and case analysis of secondary data are the key sources of information taken forward in the study on a qualitative perspective. in the qualitative analysis of ethical contributions from religions and culture, the various themes are identified and grouped based on common grounds. tabulation of the causal factors of corporate scandals, enables to clearly identify the root cause of unethical business practices and immoral leadership. the various findings are to be taken in a positive note for the future corporate businesses and ethical leadership of executives.

\section{Findings \& discussion}

\section{Ethical perspectives of major religions and cultures}

\section{Ethics \& values from Islam}

Meaning of ethics in Islam (Abdurezak, 2011): Conceptually, akhlÉq includes two meanings; first akhlÉq (ethics) means the science (Nilm) that deals with the standards of right and wrong of human conducts, particularly "what humans out to do". Second, akhlÉq means "good character" or good human behavior (alakhlÉq al-fÉlìlah). According to Jawed (2013), The fundamental ethical axioms of Islam include unity, equilibrium, free will, and responsibility and there are two primary sources of normative Islamic teachings, the first and most important source is the Qur'an and the second primary source is called "Sunnah" or "Hadeeth", which means the words, actions and approvals of Prophet Muhammad. Muslims regard Islam as a way of life and not merely a religion. The term of ethics in business or business ethics is not an issue. Since in Islam, business ethics cannot be separated from ethics because it deals with all aspects of a Muslim's daily life (Beekun and Badawi, 2005). It is further stressed by Muhammad et al. (2008) that business 
ethics is referred to moral principles, standards of code of conduct and the guidance in the business environment. A company, as suggested by Haniffa and Hudaib (2007), should maintain in good behavior, involving in social responsibility with promoting justice and welfare (al-'adl wa al-ihsan) in society and seeking God's pleasure and blessing (al-barakah). Based on some of the important verses from Qur'an relevant to business ethics and leadership, which is summarized in Table 1, we infer the high influence of Islam on business conduct and ethics especially in countries which follow the particular religion. The business managers need to understand these implications in taking major decisions when conducting businesses in such countries.

Table 1. Islamic ethics \& values on business and ethical human behavior

\begin{tabular}{|c|c|c|}
\hline $\begin{array}{c}\text { Management } \\
\text { principle and Focus }\end{array}$ & Islamic teachings & Meaning \\
\hline $\begin{array}{l}\text { Ethics on acquisition } \\
\text { and distribution of } \\
\text { wealth }\end{array}$ & $\begin{array}{l}\text { To Allah belongs the } \\
\text { dominion of the heavens and } \\
\text { the earth, and all that is } \\
\text { therein, and it is He who has } \\
\text { power over all things. } \\
\text { (Qur'an, 5:123). }\end{array}$ & $\begin{array}{l}\text { It has also other implications of trust and legitimacy as property is } \\
\text { attributed to persons, individually or collectively. } \\
\text { Legitimacy of the method of acquisition of property, excluding theft, } \\
\text { extortion, cheating of other illegitimate dealings. Enjoyment of one's } \\
\text { property should not infringe on the similar rights of others [(e.g. } \\
\text { establishing a factory in a residential area), or preventing access to } \\
\text { natural resources. } \\
\text { To pay whatever is due on property (Zakah) (Jamal, 2001). }\end{array}$ \\
\hline $\begin{array}{l}\text { Employee } \\
\text { commitment, loyalty } \\
\text { and welfare }\end{array}$ & $\begin{array}{l}\text { Labor is a potential act of } \\
\text { "worship". }\end{array}$ & $\begin{array}{l}\text { All legitimate activities and efforts exerted with pure intentions are } \\
\text { potential acts of "worship" in the broader Islamic meaning. } \\
\text { Islamic law recognizes the right of the weak, young and poor for a } \\
\text { minimum level of decent life, it discourages abuse of welfare systems or } \\
\text { exploit people's kindness when the person is able to seek work and earn } \\
\text { his living (Rice, 1999). }\end{array}$ \\
\hline $\begin{array}{l}\text { Prohibition of } \\
\text { unethical businesses } \\
\text { and production } \\
\text { guidelines }\end{array}$ & $\begin{array}{l}\text { "trespassing the limits of } \\
\text { Allah" (Qur'an, 2:229). }\end{array}$ & $\begin{array}{l}\text { The production of wines or other intoxicants is prohibited in Islam; } \\
\text { Likewise, any activity connected with gambling, prostitution or other } \\
\text { "indecencies" is restricted. } \\
\text { The method of production should not cause an undue and excessive } \\
\text { harm to resources. Both consumption and spending are qualified, } \\
\text { however, by the ethical rule of moderation and avoidance of } \\
\text { extravagance (Yousri, 2005). }\end{array}$ \\
\hline Trust & $\begin{array}{l}\text { "And those who keep their } \\
\text { trusts and promises" (Qur'an, } \\
\text { 23:8). }\end{array}$ & $\begin{array}{l}\text { Honesty in all dealing is an ethical requirement, including the fulfillment } \\
\text { of all contracts, commitments and covenants (Beekun, 1997). }\end{array}$ \\
\hline $\begin{array}{l}\text { Prohibition of } \\
\text { business speculation }\end{array}$ & $\begin{array}{l}\text { The Qur'an enjoins "..and do } \\
\text { not deprive people of their } \\
\text { due" (Qur'an, 7:85). }\end{array}$ & $\begin{array}{l}\text { One form of that exploitation which the prophet forbade is "Tanajush". } \\
\text { This refers to deceptive practices in auctions, where persons who do not } \\
\text { intend to buy simply keep bidding the price upwards [often in conspiracy } \\
\text { with the seller], so as to get others "stuck" in the deal (Beekun, \& } \\
\text { Badawi, 2005). }\end{array}$ \\
\hline $\begin{array}{l}\text { Staying away from } \\
\text { cheating }\end{array}$ & $\begin{array}{l}\text { "Anyone who cheat us is not } \\
\text { of us" - Hadeeth }\end{array}$ & $\begin{array}{l}\text { Refraining from the exploitation of the ignorance or desperate needs of } \\
\text { others by giving them less than a fair price [or wage] (Mews \& } \\
\text { Abraham, 2006). }\end{array}$ \\
\hline $\begin{array}{l}\text { Staying away from } \\
\text { business risk and } \\
\text { unfulfillable } \\
\text { promises }\end{array}$ & (Bay'ul-gharar) & $\begin{array}{l}\text { Prohibition of the sale of an item which is not available and whose } \\
\text { delivery is doubtful (Haniffa and Hudaib, 2007). }\end{array}$ \\
\hline Justice & $\begin{array}{l}\text { Adl; "Allah commands } \\
\text { justice, the doing of good and } \\
\text { liberality to kith and kin } \\
(16: 90) \text {. } \\
\text { "Lo! We have created } \\
\text { everything by measure" } \\
(18: 46) \text {. }\end{array}$ & $\begin{array}{l}\text { Justice or 'Adl means to treat people equally is a pre-requisite of fairness } \\
\text { and justice. Business Implications and Ethical perspectives implies } \\
\text { nondiscrimination and rejection of favoritism and cronyism (in hiring, } \\
\text { promotion, etc.) (Shaharuddin, 2005). }\end{array}$ \\
\hline $\begin{array}{l}\text { Truthfulness } \\
\text { (Sidqun) }\end{array}$ & $\begin{array}{l}\text { Allah says: "Oh believers! } \\
\text { Fear Allah, and say the right } \\
\text { thing" (33:70). }\end{array}$ & $\begin{array}{l}\text { Truthfulness is a basic ethical value of Islam. Islam is, in a way, the } \\
\text { other name of truth (Beekun, 1997). }\end{array}$ \\
\hline Corruption (Fasad) & $\begin{array}{l}\text { "Do no mischief on the earth, } \\
\text { after it hath been set in order, } \\
\text { but call on Him with fear and } \\
\text { longing (in your hearts): for }\end{array}$ & $\begin{array}{l}\text { According to the Qur'an, corruption (fasad), which basically means } \\
\text { misappropriate and mishandling, leads to destruction of life; hence, the } \\
\text { Qur'an commands Muslims to avoid fasad, instead it calls them to do } \\
\text { ihsan (doing good or better) (Abdurezak, 2011). }\end{array}$ \\
\hline
\end{tabular}




\begin{tabular}{|c|c|c|}
\hline & $\begin{array}{l}\text { the Mercy of Allah is } \\
\text { (always) near to those who do } \\
\text { good." (The Qur'an, 7:56). }\end{array}$ & \\
\hline Interest prohibition & $\begin{array}{l}\text { "Allah has permitted trading } \\
\text { and forbidden riba (interest)" } \\
\text { (Qur'an } 2: 275 \text { ). }\end{array}$ & $\begin{array}{l}\text { Unlike the Conventional Economics system, the Islamic economics } \\
\text { system does not recognize the opportunity cost of lending money, thus } \\
\text { there is no place for interest in Islam (Beekun, \& Badawi, 2005). }\end{array}$ \\
\hline
\end{tabular}

\section{Ethics and Values from Christianity}

According to Christoph et.al. (2016), in Christianity values and virtues are branches and fruits of a tree. Values are bench-marks, fundamental orientations for personal and social life like justice or freedom, for example the value of equity and justice is visible in the virtue of mutual respect of each other or of humanity. Premises are the basis and precondition of values and virtues, for example life, love and dignity are the preconditions for freedom and justice. They are like the roots of the tree. The fundamental Christian values includes justice/equity, compassion and caring, stewardship/servant leadership, freedom, sustainability, responsibility/accountability, participation/community, sharing/solidarity, transparency, innovativeness, peace and forgiveness.

\section{Indian version of ethics from religion \& culture}

In Hinduism philosophy Dharmasastras (ethical principles), and epics (moral legends \& classics) have their own specific goal but they seem to share more or less a common 'ethos' from the point of ethics (Ranganathan, 2007). Most of the religious influences, teachings and moral values of Hinduism revolve around the concept of Karma. Karma means action and each action has its own impact either in this birth or in next birth is the belief of Hinduism in India. And because of this Karma, mankind is entangled in a repeated cycle of births and rebirths, from which he needs to be liberated towards the supreme god. (Keshavadass, 1978). The various Indian spiritual (Vedic) texts, teachings, Epics \& Puranas (Stories), etc., of the Hinduism Religious literature, put forward various means of values, moral conducts, ethical guiding principles and examples to be taken forward for a peaceful, joyous and liberated human life. Although most of these revolve around personal values, wealth and society, some of it relevant towards business ethics and social responsibility can be taken for the research study.

The Buddha taught ten meritorious deeds for us to perform in order to gain a happy and peaceful life as well as to develop knowledge and understanding. The ten meritorious deeds are: 1. Charity, 2. Morality, 3. Mental Culture, 4. Reverence or respect, 5. Service in helping others, 6. Sharing merits with others, 7. Rejoicing in the merits of others, 8. Preaching and teaching the Dhamma, 9. Listening to Dhamma, 10. Straightening one's views. Similarly, there are ten demeritorious deeds from which the Buddhist are advised to keep away. Love, charity and wisdom are known as the "the three Good Roots." Here the word 'root' refers to the intention from which that action originates (Hindery, 1978).

The issue of good governance is discussed in Kautilya's Arthashastra, India's classic text on the art of politics and government. Kautilya was the first classical philosopher who explicitly tackled economic issues. the concept of arthashastra combined economics, politics, ethics, war and law (Jhingan, Girija, Manimekalai, \& Sasikala, 2006).

\section{Insights from Tamil literature and culture on ethics}

All aspects of the world are simple in its true form, and it is man who complicates the balance of nature, wealth and peace, ending up in total chaos and confusion. In this paper, the researcher focuses on one of the main literary work in the classical Tamil language, Tirukkural or Kural or the couplets translated in most global languages equally and at par with the famous religious texts like The Holy Bible and the Qur'an. According to Thiruvalluvar, wealth is essential but it is only a means to an end, not an end in itself. Thiruvalluvar's conclusions were remarkable: he stated that ethical values coincide with a good economy and that therefore a free market is necessary. Basically humans are naturally good and contribute positively to the economy. Thiruvalluvar limited the states involvement to defence, social security and public works. On the other hand, he considered self-sufficiency as extremely important and consequently agriculture is the basis of a sound economy (Jhingan et. al., 2006: 485-489). The various important couplets related to governance, wealth and human ethics are summarized below in Table 2 for the benefit of future managers. 
Table 2. Ethics and Virtues from The Couplet

\begin{tabular}{|c|c|c|}
\hline $\begin{array}{l}\text { Ethics and } \\
\text { management } \\
\text { focus }\end{array}$ & The couplet & Meaning \\
\hline Duty to society & $\begin{array}{l}\text { Though Seers may fall on evil days, } \\
\text { Their sense of duty never strays (Kural, 218). }\end{array}$ & $\begin{array}{l}\text { Even when the wealth gets eroded, and even in times of } \\
\text { poverty, persons in responsible positions of sacrifice } \\
\text { never fail in their duty to serve. }\end{array}$ \\
\hline $\begin{array}{l}\text { Abstaining from } \\
\text { fraud }\end{array}$ & $\begin{array}{l}\text { We will by fraud may overflow, } \\
\text { But swift to ruin it shall go (Kural, 283). }\end{array}$ & $\begin{array}{l}\text { The wealth and monetary gains earned by fraud and } \\
\text { deception, shall erode away fast even taking away the } \\
\text { existing wealth. }\end{array}$ \\
\hline $\begin{array}{l}\text { Abstaining from } \\
\text { fraud }\end{array}$ & $\begin{array}{l}\text { Virtue abides in righteous hearts, } \\
\text { Into minds of frauds deceit darts (Kural, 288). }\end{array}$ & $\begin{array}{l}\text { A person of honesty and righteous heart takes the right } \\
\text { path, whereas a heart filled with deceit and greed chooses } \\
\text { the wrong path. }\end{array}$ \\
\hline $\begin{array}{l}\text { On monarchy and } \\
\text { governance }\end{array}$ & $\begin{array}{l}\text { The able King gets, stores and guards, And } \\
\text { spends them for peoples safeguards } \\
\text { (Kural, 385). }\end{array}$ & $\begin{array}{l}\text { The role of the king or the government is to create and } \\
\text { plan the country's resources, generate wealth in the } \\
\text { treasury, safeguard and apply it for the benefit of the } \\
\text { people. }\end{array}$ \\
\hline $\begin{array}{l}\text { Leadership } \\
\text { qualities }\end{array}$ & $\begin{array}{l}\text { Courage, Giving, Knowledge and Zeal, Are } \\
\text { Four Failless features Royal (Kural, 382). }\end{array}$ & $\begin{array}{l}\text { Moral courage, Empathy, Moral Intelligence and Positive } \\
\text { thinking are four core qualities for king to adorn } \\
\text { evermore. }\end{array}$ \\
\hline $\begin{array}{l}\text { Executives moral } \\
\text { principles }\end{array}$ & $\begin{array}{l}\text { He is the Lord of Men who does sound justice } \\
\text { and saves his race (Kural, 388). }\end{array}$ & $\begin{array}{l}\text { Kural stresses the importance of moral principles that } \\
\text { king has to follow them and live to it. }\end{array}$ \\
\hline Avoiding faults & $\begin{array}{l}\text { What Fault can be the King's who cures, } \\
\text { First his faults, then scans others (Kural, 436). }\end{array}$ & $\begin{array}{l}\text { The Leader or King can never be faulty, if he first checks } \\
\text { himself for any fault, before finding fault with others. }\end{array}$ \\
\hline $\begin{array}{l}\text { Deliberation } \\
\text { before action }\end{array}$ & $\begin{array}{l}\text { Weigh well output the loss and gain, } \\
\text { And proper action ascertains (Kural, 461). }\end{array}$ & $\begin{array}{l}\text { Assessment of the costs and benefits is must before } \\
\text { jumping into or taking a course of action. }\end{array}$ \\
\hline $\begin{array}{l}\text { Deliberation } \\
\text { before action }\end{array}$ & $\begin{array}{l}\text { Doing unfit action ruins, } \\
\text { Failing fit-act also ruins (Kural, 466). }\end{array}$ & $\begin{array}{l}\text { Indulging in unworthy acts results in bad repercussions, } \\
\text { and also failing to indulge in worthy acts also results in } \\
\text { bad repercussions. }\end{array}$ \\
\hline $\begin{array}{l}\text { Testing and } \\
\text { entrusting }\end{array}$ & $\begin{array}{l}\text { Employ the wise who will discern, } \\
\text { The Good and Bad and do good turn (Kural, } \\
\text { 511). }\end{array}$ & $\begin{array}{l}\text { A person who can act in the right way after judging good } \\
\text { and bad, is fit enough to be entrusted and employable for } \\
\text { any kind of job. }\end{array}$ \\
\hline Purity of action & $\begin{array}{l}\text { Gains from weeping, weeping go, } \\
\text { Though lost, from good deeds blessings flow } \\
\text { (Kural, 659). }\end{array}$ & $\begin{array}{l}\text { Wealth gained from the tears of others wades away, } \\
\text { whereas even though wealth gets eroded in good deeds, it } \\
\text { comes back in abundance. }\end{array}$ \\
\hline Modes of action & $\begin{array}{l}\text { Delay such acts as need delay, } \\
\text { Delay not acts that need display } \\
\text { (Kural, 672). }\end{array}$ & $\begin{array}{l}\text { The actions that needs to be undertaken with patience } \\
\text { needs to take slowly and steadily, whereas the action } \\
\text { which needs immediate response needs to be prioritized. }\end{array}$ \\
\hline Modes of action & $\begin{array}{l}\text { Its best to act when feasible, } \\
\text { If not see what is possible. } \\
\text { (Kural, 672). }\end{array}$ & $\begin{array}{l}\text { The quote or verse is one of the best self-motivators. And } \\
\text { says straightforwardly that, it's best to act when feasible } \\
\text { and if not feasible also see to it to do what is possible. }\end{array}$ \\
\hline Able leadership & $\begin{array}{l}\text { Though a land has thus everything, } \\
\text { It is worthless without a King. } \\
\text { (Kural, 740). }\end{array}$ & $\begin{array}{l}\text { Even though a country may have all the resources and } \\
\text { wealth, it is of no use if there is no leader to administer it } \\
\text { righteously. }\end{array}$ \\
\hline $\begin{array}{l}\text { Ways of making } \\
\text { wealth }\end{array}$ & $\begin{array}{l}\text { Riches devoid of love and grace, } \\
\text { Off with it; it is disgrace (Kural, 755). }\end{array}$ & $\begin{array}{l}\text { Whatever may be the amount of wealth, if it comes in } \\
\text { sinful ways, it is better to refrain from such wealth. }\end{array}$ \\
\hline Futile wealth & $\begin{array}{l}\text { Other usurp the shining gold, } \\
\text { In loveless, stingy, vicious hold (Kural, 1009). }\end{array}$ & $\begin{array}{l}\text { Wealth earned unrightfully devoid of love and just, shall } \\
\text { be coveted and taken by others for sure. }\end{array}$ \\
\hline
\end{tabular}

\section{Factors contributing to corporate scandal and fraud}

According to Fortune (2016), the irresponsible way of handling the Maggi noodle ban crisis by Nestle, exposes the unethical ways of corporate behavior in the event of a crisis. Initially Nestle being questioned by the FSSAI - Food safety regulator of India, levels of Monosodium glutamate, it was further grilled for high levels of Lead in the Noodle product Maggi in successive laboratory test results. Instead of finding the root cause of the food safety issue, Nestle countered it with court battles, expensive product recalls, and fruitless media campaigns, only to lose its market to competitors and loss of brand image with customers. From the list of scandals (refer Table 3) aggregated from secondary data on Business literature, the paper attempts to do a pareto analysis in identifying the major causes of the corporate scandals of recent times from an ethical perspective. From the various ethical literature from religion, culture and other global perspectives, the pa- 
per identifies the key ethical dimensions mentioned repeatedly in the context of ethical behavior and corporate governance. It includes the dimensions of trust, honesty or transparency, abstaining from fraud, responsibility (duty) or accountability and deliberation before action (improper planning).

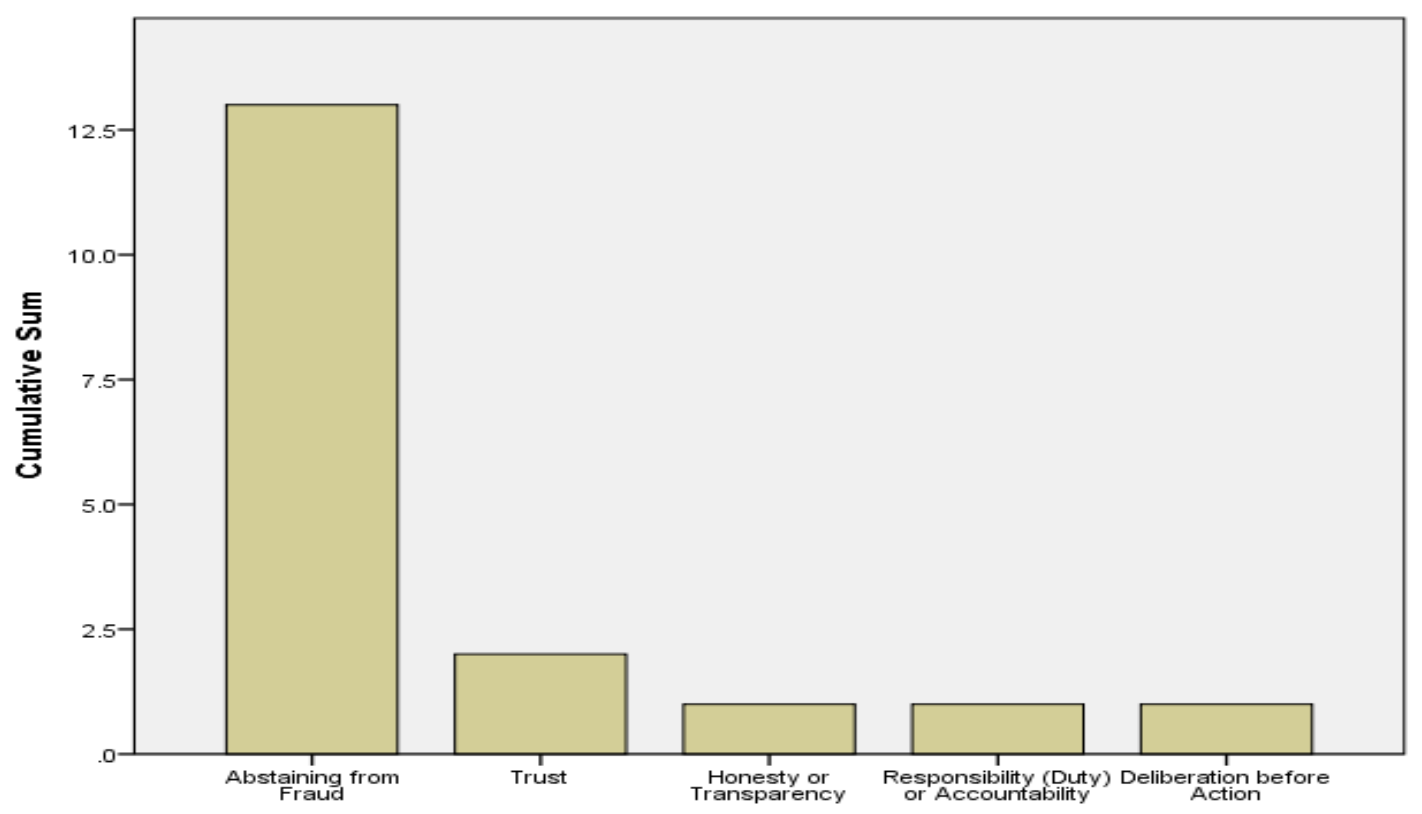

Figure 2. Pareto analysis of root causes of corporate scandals

From the pareto analysis (Figure 2) of the various corporate scandals on an ethical perspective, it is inferred that $80 \%$ of the root causes of the corporate scandals could be attributed to the ethical dimension of abstaining from fraud $(72.22 \%)$. It doesn't undermine that other dimensions have not been considered as reasons in the pareto analysis, rather more weightage has been given to this particular dimension, followed by other dimensions to be considered as a root cause under the given circumstance of the scandal. Henceforth the insight to be taken forward is the need for stringent legislations, which would keep the executives, managers and administrators of economy from involving in corporate and managerial fraud.

\section{Government sector scams and ethical implications: the case of India}

The reports by BBC (2012) \& Trak (2016), highlights the corruption scandals in the Indian Government sector in collision with businesses. The various cases of scandals includes the Telecommunication Ministry - 2 G Spectrum Scam - 2008 - 1,76,000 Crore, Army Bribery Row, Wikileaks: 'Cash for Votes', Maharashtra War Widows/Adharsh House Society Scam, Commonwealth Games Scam - 2010 - 70,000 Crore, Mining Scandals, Indian Coal Allocation Scam - 2012 - 1,86,000 Crore, Wakf Board Land Scam - 2012 1.50,000 Crore, Telgi Scam - 2002 - 20,000 Crore, Bofors Scam (155 mm field howitzer)- 1980s \& 90s 100 to 200 Crore, The Fodder Scam - 1990s - 1,000 Crore, The Hawala Scandal - 1990-91 - 100 Crore and Harshad Mehta \& Ketan Parekh Stock Market Scam - 1992 - 5000 Crore Combined. In all these cases Ethical breaches have occurred on all levels right from the centre to state and involving the key politicians of major parties who were in power. legal loopholes, increased levels of corruption, poor public governance and unethical leadership were found to be the root causes in most of the scandals.

\section{Legislations and frameworks on business ethics \& corporate governance}

After the Enron crisis, the US government enacted the Sarbanes-Oxley Act (2002), with the aim of improving financial reporting and restoring public confidence in CG and in Financial markets (Goergen, 2012). Unethical work behavior of the auditors was found to be the root cause of these accounting scandals as they have acted out of greed for their vested interests in huge monetary benefits in the form of fees for colluding with the fraudulent organizations. Hence the Sarbanes Oxyley Act, mandated for rotation of the auditors.

Corporate sustainability is reflected from its transparency that affects the society through good governance, compliance system, and adequate risk assessment program (Popoola, Ahmad, \& Samsudin, 2014). GRC is a management model that promotes the criteria unification, as well as communication and collaboration between different stakeholders. The key components of the GRC framework are as follows namely governance manages the risks to the execution of the company strategy as well as the risks from the chosen strategy; risk 
management determines the areas exposed to potential risks; compliance is the tactical action to mitigate risk (Papazafeiropoulou \& Spanaki, 2015).

\section{Conclusion}

The current global economic crisis has increased the public and legislative focus on accountability, transparency, risk management and compliance with laws and regulations. Organizations seek efficient and effective mechanisms to ensure keeping up with challenging legal requirements. Basic compliance initiatives prevent legal misbehavior, complex programs extend to areas like customer satisfaction, public reputation, transparency, ethical behavior, organizational structure and risk management (Benedek, 2012). Compliance in practice is a complex issue that requires interdisciplinary research since it lies on the borderline of law, finance, risk management and operations management.

If value considerations are to truly contribute to the organization's well-being, it must be institutionalized within an organization's ethos, culture, and operative rules of the game. Managers can adhere to the following principles to create a more ethical culture by following the steps including: be a visible role model, communicate ethical expectations, provide ethical training, visibly reward ethical acts and punish unethical ones and provide protective mechanisms for handling ethical dilemmas (Mulki, Jaramillo, Locander, 2009).

The paper concludes that the modern day business and its legal and accountability mechanism are hardly a few hundred years old, existing in todays globalized world. And this form of modern day business needs to look into ethical values and moral principles explored in the study from the various cultural and religious dimensions, and can aid in preventing ethical misconduct and improving corporate sustainability, brand image and reputation.

\section{References}

1. Abdurezak A. H. (2011). Islamic ethics: An outline of its principles and scope. Revelation and Science, 1(3), 122-130.

2. Acharya, G. (2012). India: Case Study on the Supreme Court Ruling on the 2 G Spectrum Scam (February 27, 2012). Available at SSRN: https://ssrn.com/abstract $=2048719$ or http://dx.doi.org/10.2139/ssrn.2048719.

3. Agananooru (n.d.). Retrieved Online from: http://literature-comp.blogspot.com/2011/10/best-of-what-ihave-read-tamil-sangam_30.html.

4. Ajzen, Icek and Mark Fishbein (1975). Belief, Attitude, Intention and Behavior: An Introduction to Theory and Research. Reading, Mass: Addison-Wesley.

5. Amini, M., \& Bienstock, C. C. (2014). Corporate sustainability: An integrative definition and framework to evaluate corporate practice and guide academic research. Journal of Cleaner Production, 76, 12-19. https://doi.org/10.1016/j.jclepro.2014.02.016.

6. Baker, J. (2015). The FIFA Scandal: Lessons for the Corporate World. ACFE Asia-Pacific Fraud Conference, 1, 1-25. https://doi.org/10.1017/CBO9781107415324.004.

7. BBC (2016). India's corruption scandals. Retrieved (13th Nov 2017) from: http://www.bbc.com/news/world-south-asia-12769214.

8. Beekun, R. I. (1997). Islamic Business Ethics. Beltsville: The international Institute of Islamic Thought.

9. Beekun, R. I., \& Badawi, J. A. (2005). Balancing Ethical Responsibility among Multiple Organizational Stakeholders: The Islamic Perspective. Journal of Business Ethics, 60(2), 131-145.

10. Benedek, P. (2012). Compliance management - A new response to legal and business challenges. Acta Polytechnica Hungarica, 9(3), 135-148.

11. Business-anti-corruption. (2017). India Corruption Report. Retrieved (15th Nov 2017) from: http://www.business-anti-corruption.com/country-profiles/india.

12. Carroll, A. B. (1991). The Pyramid of Corporate Social Responsibility: Toward the Morai Management of Organizational Stakeholders. Business Horizons, 39-48. https://doi.org/10.1016/00076813(91)90005-G.

13. Christoph, S., Cui, W., Teodorina, L., Wang, D., Liu, Y., Zhang, Y. (2016). Entrepreneurs with Christian Values, Handbook for 12 Modules. Geneva: Globethics.net.

14. Cipoletti, C. (2013). Three Steps in the Ethical Decision-Making Process. Retrieved February 8, 2013, from http://www.ehow.com/info_8752987_three-steps-ethical-decisionmakingprocess.html. 
15. Colquitt, J. A., Scott, B. A. and LePine, J. A. (2007). Trust, Trustworthiness, and Trust Propensity: A Meta-Analytic Test of Their Unique Relationships with Risk Taking and Job Performance. Journal of Applied Psychology, 9(4), 909-927.

16. Di Lorenzo, V. (2007). Business ethics: Law as a determinant of business conduct. Journal of Business Ethics, 71(3), 275-299. http://doi.org/10.1007/s10551-006-9139-9

17. Di Miceli da Silveira, A. (2013). The Enron Scandal a Decade Later: Lessons learned? Homo Oeconomicus, 30(3), 315-347. https://doi.org/10.2139/ssrn.2310114.

18. Drucker, P. (1981). What is business ethics? National Affairs, 63, 18-36.

19. Feiser, J. (2003). Ethics. The internet encyclopedia of philosophy. http://www.utm.Edu/research/iep/e/ethics.htm/ (accessed November 7, 2017).

20. Fortune (2016). Nestlé's Half-Billion-Dollar Noodle Debacle in India. Retrieved (15th Nov 2017) from: http://fortune.com/nestle-maggi-noodle-crisis/

21. Fortune (2016). The 5 Biggest Corporate Scandals of 2016: Retreived Online (3rd Nov 2017) from: http://fortune.com/2016/12/28/biggest-corporate-scandals-2016/

22. Ghazi-Tehrani, A. K., \& Pontell, H. N. (2015). Corporate crime and state legitimacy: the 2008 Chinese melamine milk scandal. Crime, Law and Social Change, 63(5), 247-267. https://doi.org/10.1007/s10611-015-9567-5

23. Goergen, M. (2012). International corporate governance. Englewood Cliffs, NJ: Prentice-Hall.

24. Grebe, S. K. (2013). The importance of being genuinely sorry when organizations apologize: How the Australian Wheat Board (AWB Limited) was damaged even further by its response to a corporate scandal. Journal of Public Affairs, 13(1), 100-110. https://doi.org/10.1002/pa.1450.

25. Haniffa, R. \& Hudaib, M. (2007). Exploring the Ethical Identity of Islamic Banks via Communication in Annual Reports. Journal of Business Ethics, 76(1), 97-116.

26. Hindery, R. (1978). Comparative Ethics in Hindu and Buddhist Traditions. New Delhi: Motilal Banarsidas.

27. Hotten, R. (2015). Volkswagen: The scandal explained. BBC News, pp. 1-14. Retrieved from http://www.bbc.com/news/business-34324772.

28. Iannaccone, Laurence R., Finke, R. and Stark, R. (1997). Deregulating Religion: The Economics of Church and State. Economic Inquiry, 35(2), 350-364.

29. Jamal A. B. (2001). Islamic Business Ethics. Saint Mary's University, Halifax, N.S., Canada. DOI: 10.5840/spiritgds200127. Retreived (9th Nov 2017) from: https://www.researchgate.net/profile/Jamal_Badawi/publication/268002558_Islamic_Business_Ethics/links/ 5622edda08aed8dd19441573/Islamic-Business-

Ethics.pdf?origin=publication_detail\&ev=pub_int_prw_xdl\&msrp=oel1h9beoV8dj_EqHt4TTLquoILR2CYb9iH1EE9GzuEmSujpcBWA9d1ESw3ELbQ0sbvnyZATs_iLMhStirt8HudkoIevabUNu Zo8D3FI-huk-34WE1BpDzC.nuZlvKNywXD6XyuVkg6PO2QahdGUJtmAkLQqlURZyIhp--

z_SpiD5F9vBbyGeCMaQ2wtyWFprkHBI49WgdkuOhzYEoZSx_CAV8ZICA.NRbbcWLbFRxSY6oNcMlmcYrR-dK9Ri9PSJeUPf4Fs6V66qPIIZbglGtBmiC-

DlnpCJBuRbCCWEEfxseAIhWi_1PiArU1hJnJs89aw.01UtCJh5_J76vANzWniB0DVXY2MtjuygiOI8KjhVfGjo72xIClAFOm_39L K4a3YA-kYtCG3fGSUDoUErV2MbgAARbU-DAWGNeCL3zA.

30. Jawed, A. M. (2013). A Conceptual Framework of Business Ethics in Islam. Handbook of the Philosophical Foundations of Business Ethics. pp 899-932. DOI: 10.1007/978-94-007-1494-6_5

31. Jhingan, M. L., Girija, M., Manimekalai, A. \& Sasikala, L. (2006). History of Economic Thought. Delhi: Vrinda Publications.

32. Jones, G. R. \& George, J. M. (2009). Contemporary Management (6th Edition). New York: McGraw Hill.

33. Jong, A. de, DeJong, D. V., Mertens, G., \& Roosenboom, P. (2005). Royal Ahold A Failure of Corporate Governance an Accounting Scandal. CentERO, 57, 1-57. https://doi.org/10.2139/ssrn.663504.

34. Kazuo, M. (2015). Toshiba Accounting Scandal Highlights Issues in Corporate Governance. Retrieved from http://www.nippon.com/en/in-depth/a04802/.

35. Keshavadass, S. (1978). Liberation from Karma and Rebirth. Bombay: Bharathiya Vidhya Bhavan.

36. Kural (n.d.). Project Madurai 1999. Retrieved from: http://www.projectmadurai.org/pm_etexts/pdf/pm0017.pdf.

37. Mews, C. J., \& Abraham, I. (2006). Usury and Just Compensation: Religious and Financial Ethics in HIstoriacal Perspective. Journal of Business Ethics , 1-15. 
38. Miwa, Y. (2006a). Institutional investors and corporate governance. In N. Demise, Y. Miwa, M. Nakabayashi, \& Y. Nakoshi (Eds.). Corporate governance in Japan-From the viewpoints of management, accounting and the market pp. 31-38. Tokyo: Springer. http://dx.doi.org/10.1007/978-4-431-30920-8_4.

39. Mohammed B. Hemraj (2004). Preventing corporate scandals. Journal of Financial Crime, 11(3), 268276. https://doi.org/10.1108/13590790410809202.

40. Muhammad, M. Z., Ilias, A., Ghazali, M. F., Abdullah, R. C., \& Amin, H. (2008). An Analysis of Islamic Ethics in Small and Medium Enterprises (SMEs). UNITAR E-journal, 4, 46-58.

41. Mulki J. P., Jaramillo, J. F. and Locander, W. B. (2009). Critical Role of Leadership on Ethical Climate and Salesperson Behaviors. Journal of Business Ethics, 86(2), 125-141.

42. Papazafeiropoulou, A., \& Spanaki, K. (2016). Understanding governance, risk and compliance information systems (GRC IS): The experts view. Information Systems Frontiers, 18(6), 1251-1263. https://doi.org/10.1007/s10796-015-9572-3.

43. Pavlovich, K., Sinha, P. N., \& Rodrigues, M. (2016). A qualitative case study of MNE legitimacy: The Fonterra-Sanlu IJV corporate milk scandal in China. International Journal of Emerging Markets, 11(1), 42-56. https://doi.org/10.1108/IJoEM-02-2014-0018

44. Ranganathan, S. (2007). Ethics and the History of Indian Philosophy. Delhi: Motilal Banarsidass.

45. Rhodes, C. (2016). Democratic Business Ethics: Volkswagen's Emissions Scandal and the Disruption of Corporate Sovereignty. Organization Studies, 37(10), 1501-1518. https://doi.org/10.1177/0170840616641984.

46. Rokeach .M. (1973). The Nature of Human Values, pp. 5-6. New York: The Free Press.

47. Russell, G. W. (2015). Will Toshiba's scandal bring about the change needed in corporate governance? GAA Accounting. Retrieved from http://www.gaaaccounting.com/toshiba-scandal-corporategovernance.

48. Sammi, C. (2013). Corporate Social Responsibility: Definition and Examples. Www.Businessnewsdaily.Com. Retrieved from http://www.businessnewsdaily.com/4679-corporatesocial-responsibility.html.

49. Shailer, G. (2004). An introduction to corporate governance in Australia. Sydney: Pearson Education Australia.

50. Simpson, J. A.(2007). Psychological Foundations of Trust. Current Directions in Psychological Science, 16(5), pp. 264-268.

51. Tayan, B. (2016). The Wells Fargo Cross-Selling Scandal. Stanford Closer Look Series. Retrieved from https://papers.ssrn.com/sol3/papers.cfm?abstract_id=2879102.

52. Trak (2016). Top 10 Corruption Scams in India. Retrieved (13th Nov 2017) from: http://trak.in/2010/top-10-corruption-scams-scandals-india/.

53. Tricker, A. (2009). Essentials for board directors: An A-Z guide. New York: Bloomberg Press.

54. Walker, K. (2010). A Systematic Review of the Corporate Reputation Literature: Definition, Measurement, and Theory. Corporate Reputation Review, 12(4), 357-387. https://doi.org/10.1057/crr.2009.26.

55. Wolfgang, J. (2009). The Impact of Religion on Values and Behavior. Kwansei Gakuin University. Graduate School of Sociology, Nishinomiya, Japan. Accessed (6th Nov 2017) from: https://www.kwansei.ac.jp/s_sociology/attached/6511_53856_ref.pdf.

56. Yousri, A. R. (2005). Sustainable Development: An Evaluation of Conventional and Islamic Perspectives. In M. Iqbal, Islamic Perspectives on Sustainable Development, pp. 22-57. New York: Palgrave Macmillan.

57. Zingales, B. L. (2004). Want to Stop Corporate Fraud? Pay Off Those Whistle-Blowers. Business, pp. 2-4. Retrieved from http://savingcapital.server101.com/corpfraud.pdf.

58. Zona, F., Minoja, M., \& Coda, V. (2013). Antecedents of Corporate Scandals: CEOs' Personal Traits, Stakeholders' Cohesion, Managerial Fraud, and Imbalanced Corporate Strategy. Journal of Business Ethics, 113(2), 265-283. https://doi.org/10.1007/s10551-012-1294-6. 


\section{Appendix}

Table 3. List of corporate scandals from business literature in recent decade

\begin{tabular}{|c|c|c|c|c|c|}
\hline No. & Scandal description / SOURCE & Company & Sector & Type & Impact \\
\hline 1 & $\begin{array}{l}\text { Fraudulent opening of customer } \\
\text { accounts \& closing by employees to } \\
\text { achieve sales targets, under undue } \\
\text { pressure from executives (Tayan, } \\
\text { 2016). }\end{array}$ & $\begin{array}{l}\text { Wells Fargo, } \\
\text { USA }\end{array}$ & Banking & $\begin{array}{l}\text { Serious/ } \\
\text { top }\end{array}$ & $\begin{array}{l}\text { The bank was forced to return } \\
\$ 2.6 \text { million in ill-gotten fees } \\
\text { and pay } \$ 186 \text { million in fines to } \\
\text { the government. } \\
\text { Loss of reputation, due to } \\
\text { slamming by media and } \\
\text { government. }\end{array}$ \\
\hline 2 & $\begin{array}{l}\text { VW cheating pollution emissions } \\
\text { tests in the US (Hotten, 2015). } \\
\text { Volkswagen's decision to nominate } \\
\text { a long-serving executive as } \\
\text { chairman was the root cause } \\
\text { (Rhodes, 2016). }\end{array}$ & $\begin{array}{l}\text { Volkswagen, } \\
\text { Germany }\end{array}$ & Automobile & $\begin{array}{l}\text { Serious / } \\
\text { top }\end{array}$ & $\begin{array}{l}\text { Customer deception. } \\
\text { Fraud. } \\
\text { Loss of reputation, brand } \\
\text { image. } \\
\text { Unethical corporate governance } \\
\text { and culture. }\end{array}$ \\
\hline 3 & $\begin{array}{l}\text { Exorbitant increase in drug } \\
\text { administration device (Epipen) price } \\
\text { by } 400 \% \text { which is used to } \\
\text { administer epinephrine for food } \\
\text { allergy in children } \\
\text { (Monopoly of industry. Fortune, } \\
\text { 2016). }\end{array}$ & $\begin{array}{l}\text { Mylan Drug } \\
\text { Company, } \\
\text { USA }\end{array}$ & Pharma & $\begin{array}{l}\text { Serious / } \\
\text { top }\end{array}$ & $\begin{array}{l}\text { Consumers \& families } \\
\text { struggled with sky rocket } \\
\text { pricing. } \\
\text { Bad publicity hit Mylan's stock } \\
\text { price. } \\
\text { Medicaid fraud probe was } \\
\text { initiated into the drug maker's } \\
\text { pricing. }\end{array}$ \\
\hline 4 & $\begin{array}{l}\text { Exploding of Batteries of Samsung } \\
\text { Galaxy Note } 7 \text { (Fortune, 2016). }\end{array}$ & $\begin{array}{l}\text { Samsung, } \\
\text { South Korea }\end{array}$ & $\begin{array}{l}\text { Consumer } \\
\text { electronics }\end{array}$ & $\begin{array}{l}\text { Serious / } \\
\text { middle } \\
\text { level }\end{array}$ & $\begin{array}{l}\text { Customer safety was } \\
\text { jeopardized. } \\
\text { Ban of the mobile phone in } \\
\text { flights. } \\
\text { Loss of customer reputation, } \\
\text { brand image. } \\
\text { Lead to lawsuits and a PR } \\
\text { nightmare. }\end{array}$ \\
\hline 5 & $\begin{array}{l}11.5 \text { million documents, comprising } \\
1.5 \text { terabytes of data, were stolen } \\
\text { from the Panamanian law firm } \\
\text { (Fortune, 2016). }\end{array}$ & $\begin{array}{l}\text { Panamanian } \\
\text { law firm } \\
\text { Mossack } \\
\text { Fonseca }\end{array}$ & $\begin{array}{l}\text { Legal services / } \\
\text { information }\end{array}$ & $\begin{array}{l}\text { Moderate } \\
\text { / Middle } \\
\text { Level }\end{array}$ & $\begin{array}{l}\text { The leak exposed myriad ways } \\
\text { in which the global elite are } \\
\text { able to hide their wealth from } \\
\text { tax authorities. }\end{array}$ \\
\hline 6 & $\begin{array}{l}\text { Hampton Creek employees and } \\
\text { contractors had bought company's } \\
\text { products at retail outlets, effectively } \\
\text { inflating the sales numbers. Raised } \\
\text { money using claims about its } \\
\text { products' environmental } \\
\text { sustainability that were later } \\
\text { disproved (Fortune, 2016). }\end{array}$ & $\begin{array}{l}\text { Hampton } \\
\text { Creek - } \\
\text { Vegan Mayo } \\
\text { Maker, USA }\end{array}$ & Food & $\begin{array}{l}\text { Serious / } \\
\text { Top Level }\end{array}$ & $\begin{array}{l}\text { Misrepresentation of facts. } \\
\text { Exaggeration of product value. } \\
\text { Customer deception. } \\
\text { Investor deception. } \\
\text { Window dressing. }\end{array}$ \\
\hline 7 & $\begin{array}{l}\text { Racketeering, fraud, and money } \\
\text { laundering by FIFA. } \\
\text { Corruption in conducting business } \\
\text { (Baker, 2015). }\end{array}$ & FIFA & Sports & $\begin{array}{l}\text { Serious / } \\
\text { Top }\end{array}$ & $\begin{array}{l}\text { Arrests of numerous FIFA } \\
\text { officials for monetary crime, } \\
\text { fraud. } \\
\text { Resignation of FIFA President, } \\
\text { Sepp Blatter. } \\
\text { Loss of reputation, face value. }\end{array}$ \\
\hline 8 & $\begin{array}{l}\text { Failures in corporate governance of } \\
\text { Royal Ahold (Koninklijke Ahold } \\
\text { NV). } \\
\text { Exploitation of legal and existing } \\
\text { regulatory structures to maintain } \\
\text { absolute control of the company } \\
\text { (Jong, DeJong, Mertens \& } \\
\text { Roosenboom, 2005). }\end{array}$ & Royal Ahold & Finance & $\begin{array}{l}\text { Serious / } \\
\text { Top }\end{array}$ & $\begin{array}{l}\text { Loss of investor confidence. } \\
\text { Bad acquisitions, accounting } \\
\text { scandal. }\end{array}$ \\
\hline 9 & $\begin{array}{l}\text { Australian Wheat Board's, United } \\
\text { Nations Oil-for-Food scandal } \\
\text { (Grebe, 2013). }\end{array}$ & $\begin{array}{l}\text { Australian } \\
\text { Wheat } \\
\text { Board } \\
\text { (AWB } \\
\text { Limited) }\end{array}$ & Government & $\begin{array}{l}\text { Serious / } \\
\text { Top }\end{array}$ & $\begin{array}{l}\text { Damage to corporate reputation. } \\
\text { Poor handling of the crisis. } \\
\text { Covering up of the crisis. }\end{array}$ \\
\hline
\end{tabular}


Table 3 (cont.). List of corporate scandals from business literature in recent decade

\begin{tabular}{|c|c|c|c|c|c|}
\hline No. & Scandal description / SOURCE & Company & Sector & Type & Impact \\
\hline 10 & $\begin{array}{l}\text { Enron's accounting manipulations, } \\
\text { rather than being the cause of the } \\
\text { problems, were the consequence of } \\
\text { managerial failures and wishful } \\
\text { blindness by its stakeholders (Di } \\
\text { Miceli da Silveira, 2013). }\end{array}$ & Enron, USA & Energy & $\begin{array}{l}\text { Serious / } \\
\text { Top }\end{array}$ & $\begin{array}{l}\text { Misrepresentation of facts. } \\
\text { Customer deception. } \\
\text { Investor deception. } \\
\text { Window dressing. } \\
\text { Accounting fraud. }\end{array}$ \\
\hline 11 & $\begin{array}{l}\text { US } \$ 1.2 \text { billion profit padding at } \\
\text { Toshiba. (Russell, 2015). } \\
\text { Despite of Corporate Governance } \\
\text { practices, investigations revealed } \\
\text { that the company's top executives } \\
\text { were complicit in fraudulent } \\
\text { accounting (Kazuo, 2015). }\end{array}$ & $\begin{array}{l}\text { Toshiba, } \\
\text { Japan }\end{array}$ & Electronics & $\begin{array}{l}\text { Serious / } \\
\text { Top }\end{array}$ & $\begin{array}{l}\text { Misrepresentation of facts. } \\
\text { Investor deception. } \\
\text { Window dressing. } \\
\text { Accounting fraud. } \\
\text { Unethical practices, and } \\
\text { fraudulent culture in top } \\
\text { management. }\end{array}$ \\
\hline 12 & $\begin{array}{l}\text { Parmalat scandal, which follows } \\
\text { massive corporate irregularities at } \\
\text { U.S. companies such as Enron, } \\
\text { WorldCom, HealthSouth and Tyco, } \\
\text { is merely the most outrageous recent } \\
\text { example of a common problem: } \\
\text { financial markets plagued by fraud } \\
\text { (Zingales, 2004). }\end{array}$ & $\begin{array}{l}\text { Parmalat, } \\
\text { Italy }\end{array}$ & Food & $\begin{array}{l}\text { Serious / } \\
\text { Top }\end{array}$ & $\begin{array}{l}\text { Misrepresentation of facts. } \\
\text { Investor deception. } \\
\text { Window dressing. } \\
\text { Accounting fraud. } \\
\text { Unethical practices, and } \\
\text { fraudulent culture in top } \\
\text { management. }\end{array}$ \\
\hline 13 & $\begin{array}{l}2008 \text { melamine milk scandal, China } \\
\text { (Ghazi-Tehrani \& Pontell, 2015). }\end{array}$ & China & $\begin{array}{l}\text { Food / } \\
\text { Government }\end{array}$ & $\begin{array}{l}\text { Serious / } \\
\text { Top }\end{array}$ & $\begin{array}{l}\text { Capital accumulation and } \\
\text { political legitimization. } \\
\text { Increases in the economic } \\
\text { crime rate. } \\
\text { Organization of unethical } \\
\text { business practice under state } \\
\text { authoritarian rule. }\end{array}$ \\
\hline 14 & $\begin{array}{l}\text { Case of Banca Popolare di Lodi, an } \\
\text { Italian bank involved in a corporate } \\
\text { scandal in year } 2005 \text { (Zona, Minoja, } \\
\& \text { Coda, 2013). }\end{array}$ & $\begin{array}{l}\text { Banca } \\
\text { Popolare di } \\
\text { Lodi, Italy }\end{array}$ & Banking & $\begin{array}{l}\text { Serious / } \\
\text { Top }\end{array}$ & $\begin{array}{l}\text { Managerial fraud. } \\
\text { Investor deception. }\end{array}$ \\
\hline 15 & $\begin{array}{l}\text { Fonterra-Sanlu milk-powder } \\
\text { scandal, China (Pavlovich, Sinha, \& } \\
\text { Rodrigues, 2016). }\end{array}$ & & Food & $\begin{array}{l}\text { Serious / } \\
\text { Top }\end{array}$ & $\begin{array}{l}\text { Capital accumulation and } \\
\text { political legitimization. } \\
\text { Increases in the economic } \\
\text { crime rate. } \\
\text { Unethical business practice } \\
\text { under state authoritarian rule. }\end{array}$ \\
\hline
\end{tabular}

